\title{
Optimization of Malted Sorghum Protein Extraction by Response Surface Methodology
}

\author{
IRAKOZE PIERRE CLAVER ${ }^{1 *}$ and SINDAYIGAYA ERNEST ${ }^{2}$ \\ ${ }^{1}$ Université du Burundi, Institut Supérieurd'Agriculture, \\ ${ }^{2}$ Département de TIAA. BP. 35 Gitega, Burundi
}

\begin{abstract}
Four independent variables viz. ultrasonic power, $p H$, extraction time and solvent/meal ratio were selected. The extraction process was evaluated by a selected response like protein yield and the second-order model obtained revealed $96.7 \%$ of coefficient of determination. Selected response, which evaluated the extraction process, was protein yield and the secondorder model obtained for protein yield revealed a coefficient of determination of $96.7 \%$. The optimal extraction conditions for protein were determined as follows; Ultrasonic power, $\mathrm{pH}$, extraction time and solvent/meal ratio were 400W, 8.0, 40min, and 20:1 (v/w) respectively. Protein yield was primarily affected by Ultrasonic power, $\mathrm{pH}$ and solvent/meal ratio. These conditions resulted in protein yield of $5.43 \mathrm{~g}$ of soluble protein from extract/100 g malted sorghum flour, which was agreed closely with the predicted value $5.36 \%$. The adequacy of the model was confirmed by extracting the protein under optimum values using the model. These results may help in designing the process of optimal protein extraction from malted sorghum flour.
\end{abstract}

Keywords: Response surface methodology, Malted sorghum, Optimization, Protein extraction

\section{Introduction}

Sorghum is an extremely important crop in Asia, Africa and other semi-arid regions of the world due to it's relatively drought tolerance compared to other cereals (Anglani, 1998). It can grow under very harsh conditions such as infertile soils and excessive heat, conditions that are unsuitable for maize or wheat production. Sorghum is nutritionally equivalent to most cereals, and its protein content is quite variable. However, for human nutrition sorghum protein is deficient in critical amino acids, most importantly lysine (FAO, 1995; FAO, 2002). Most literatures report several instances of levels ranging from 6 to 16 (Hoseney et al., 1994).

Recently, there has been increased interest in sorghum as a gluten-free cereal to substitute the gluten-rich cereals in the diet of people suffering from celiac disease (Elkhalifa et al., 2005). The functional properties of sorghum proteins can be used to define how flour proteins can be used to supplement or replace more toxic protein sources. Extraction of proteins is desirable for the utilization of any new protein material and can be added in small amounts to food products for a specific aspect (Ghavidel and Prakash, 2006).

Malting has been identified as a traditional processing technology that could possibly be used to improve the nutritional quality of the protein (Wang and Fields, 1978). The process of malting comprises three unit operations, viz. steeping, germination and drying. A number of factors are known to have an effect on the development of enzymes synthesized during germination and thus on the quality of the malt produced. Some authors studied the increase of efficiency of sorghum water extract (Abdul et al., 1999; Randhawa et al., 2002; Muhammad et al., 2005).

\footnotetext{
*Corresponding author, E-mail: irakozefr@yahoo.fr
}

Various parameters such as $\mathrm{pH}$, temperature, ultrasonic power, ionic strength, solvent type, extraction time, solvent/meal ratio, presence of components causing linking, affect protein extractability (Wani et al., 2006). The extraction, isolation and fractionation procedures differ depending on the end use. Generally, protein concentrates or isolates are prepared by the extraction of protein-rich material in alkaline solution which is then precipitated at isoelectric $\mathrm{pH}$ between 4.0 and 5.0 for food application (Mwasaru et al., 2000; Aluko and McIntosh, 2001; Chavan et al., 2001; Chove et al., 2001; Lqari et al., 2002; Bilgi and Celik, 2004; Aluko et al., 2005).

Response Surface Methodology (RSM) is an affective statistical technique for optimizing complex processes. It is wide used in optimizing the extraction process variables, such as protein, polysaccharides, anthocyanins, Vitamin-E and phenolic compounds from varied materials (Qiao et al., 2009).

In this study, the main objective was to optimize the extraction of protein from Chinese malted sorghum. RSM was designed to systemic analyze the effects of extraction parameters on the yields of protein from Chinese malted sorghum.

\section{Materials and Methods \\ Materials: Sorghum (Sorghum bicolor L. Moench) was purchased from the local market. All the chemicals used were of analytical grade and purchased from Sinopharm Chemicals Reagent Company (SCRC), Shanghai, China.}

Soaking, malting and preparation of sorghum flour: After removing chaff and unviable grain, sorghum grains (1000 g) were thoroughly cleaned by washing with tap water and then soaked in wooden ash extract. The grains were soaked for 24 $\mathrm{h}$ at $30^{\circ} \mathrm{C}$ with the soaking water being changed at $6 \mathrm{~h}$ interval. After soaking, the grains were spread on jute bags and covered 
with the same material in a secluded and dark area. Malting was allowed to proceed for different time intervals $(3,5$ and 6 days) and the temperature of malting kernels was $25^{\circ} \mathrm{C}$. The growth was terminated by kilning in a forced air oven at $40^{\circ} \mathrm{C}$ for $24 \mathrm{hr}$. The withered rootless were gently brushed off and dried grain were milled using a bench-top attrition mill (Dade, DFT-600, 25000 rpm, Zhejiang Linda Mechanic Co., Ltd., China). The resultant flour was sieved into a particle size of 70-mesh. The flour was then packaged in a low density polyethylene bag and was stored using plastic containers with lids in a refrigerator at $4^{\circ} \mathrm{C}$ for later analysis.

Protein extraction: Malted sorghum flour meal was extracted with selected 29 combinations of independent variables such as $\mathrm{pH}(7.0-9.0)$, solvent/meal ratio $(10: 1$ to $30: 1 \mathrm{v} / \mathrm{w})$ and extraction time (mixing) (20-60 min) (Table I). Malted sorghum flour $(10 \mathrm{~g})$ was extracted with deionized water in a stirred glass vessel at constant temperature. The $\mathrm{pH}$ of suspension was kept constant during extraction time by adjusting with $0.5 \mathrm{~mol}$ equiv/L $\mathrm{NaOH}$ or $0.5 \mathrm{~mol}$ equiv/L HCl. Ultrasonic treatment was performed in an ultrasonic cell disintegrator (JBT/C-YCL400T, Xinzhi Biotechnology and Science Inc., Lingbo, Henan Province, China) with $50 \mathrm{ml}$ of Chinese malted sorghum slurry exposed to extract for $20 \mathrm{~min}$ time at varied ultrasonic power. Ice bathing was used to ensure the temperature of solution was below $50^{\circ} \mathrm{C}$ in the whole extraction processing.

The slurry was centrifuged (ZOPR-52D refrigerating centrifuge) at $10,000 \mathrm{rpm}$ for $20 \mathrm{~min}$, the supernatant was collected and the soluble protein content was determined according to the method of Lowry, Rosebrough et al., (1951). All the experiments were carried out in triplicate.

Proximate analysis: Moisture, crude fat, crude protein and ash content were determined according to the methods of AOAC, (1997).

Experimental design and statistical analysis: Response surface methodology was used to determine the influence of four independent variables and the optimum conditions of protein isolation. The process variables and the responses were defined from published data (Rustom et al., 1991; Oomah et al., 1994; Liadakis et al., 1995; Liadakis et al., 1998; Mizubuti et al., 2000; Moure et al., 2002; Quanhang and Caili, 2005). The effect of the variables ultrasonic power $\left(\mathrm{X}_{1}\right), \mathrm{pH}\left(\mathrm{X}_{2}\right)$, extraction time (mixing) $\left(\mathrm{X}_{3}\right)$ and solvent to meal ratio $\left(\mathrm{X}_{4}\right)$ in malted sorghum protein isolation process was investigated. Each variable was coded at five levels: -2, -1, 0, 1, 2 (Table 1).
Table 1. Variables and levels for central composite design

\begin{tabular}{clllllll}
\hline Variable & Symbol & \multicolumn{6}{c}{ Coded variables levels ${ }^{\mathbf{a}}$} \\
\cline { 3 - 7 } & & -2 & -1 & 0 & 1 & 2 \\
\hline Ultrasonic & & 300 & 350 & 400 & 450 & 500 \\
power (W) & $\mathrm{X} 1$ & 7 & 7.5 & 8 & 8.5 & 9 \\
$\mathrm{pH}$ & $\mathrm{X} 2$ & 20 & 30 & 40 & 50 & 60 \\
$\begin{array}{c}\text { Extraction time } \\
\text { (mixing) }\end{array}$ & $\mathrm{X} 3$ & 10 & 15 & 20 & 25 & 30 \\
$\begin{array}{c}\text { Solvent to meal } \\
\text { ratio (v/w) }\end{array}$ & $\mathrm{X} 4$ & 15
\end{tabular}

aPassage from coded variable $\left(\mathrm{X}_{\mathrm{i}}\right)$ level to natural variable $\left(\mathrm{x}_{\mathrm{i}}\right)$ level is given by the following equations: $\mathrm{x}_{1}=5 \mathrm{X}_{1}+40 ; \mathrm{x}_{2}=0.5 \mathrm{X}_{2}+8.0$; $\mathrm{x}_{3}=10 \mathrm{x}_{3}+40 ; \mathrm{x}_{4}=\left(5 \mathrm{X}_{4}+20\right)$

The variables were coded according to the following equation; $\mathrm{X}_{\mathrm{i}}=\left(\mathrm{x}_{\mathrm{i}}-\bar{x}_{\mathrm{i}}\right) / x_{i}$ .1

Where, $\mathrm{X}_{\mathrm{i}}$ is the dimensionless value of an independent variable, $x_{i}$ is the real value of an independent variable, ${ }_{i}$ is the real value of an independent variable at the center point, " $x_{i}$ is the step change.

The response function investigated was $\mathrm{Y}_{=} \mathrm{g}$ of soluble protein from extract/100 g flour. A Central Composite Design (CCD) was arranged to allow for fitting of second-order model (Nakai and Dou, 2006) (Table 2). The CCD combined the vertices of hybercube whose coordinates were given by $2 \mathrm{n}$ factorial design (runs 1-16) with the star points (runs 17-24). The star points were added to the factorial design to provide for estimation of curvature of the model. Five replicates at the center point of the design (runs 25-29) were used to allow for the estimation of the pure error sum of squares. All experiments were carried out in a randomized order to minimize any effect of extraneous factors on the observed responses.

The model proposed for response (Y) was;

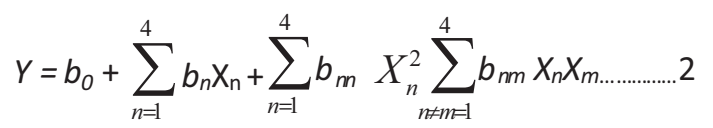

Where, $b_{0}$ is the value of the fitted response at the center point of the design, which is point $(0,0,0,0) . b_{n}, b_{n n}$ and $b_{n m}$ are the linear, quadratic and interaction regression terms respectively. The objective in the optimization process was to find a common value for the dependent variables; thus we used the desirability method. The Statistical Analysis System (28) software Version 6.03 was used in all statistical analysis and evaluation.

Predicted values (Y) is transformed into a value of $\mathrm{d}$, which falls in the range $[0,1]$ by using Design-Expert 7.1 and measures the desirability degree of the response in reference to the optimum value intended to be reached. In our case, we wanted dependent variable to be in range. The ideal optimum value is $\mathrm{d}=1$; an acceptable value for $\mathrm{d}$ can be between 0.6 and $0.8(0.6<\mathrm{d}<0.8)$. The optimum condition was verified by conducting experiments under these conditions. Surface plots 
were generated by assigning constant (zero) values to two of the four variables and solving the fitted equations as a quadratic equation in the remaining two variables.

\section{Table2. Central composite design arrangement, responses for protein yield}

\begin{tabular}{|c|c|c|c|c|c|c|}
\hline \multirow[t]{2}{*}{ Run } & \multicolumn{4}{|c|}{ Actual values } & \multicolumn{2}{|c|}{ Protein yield (Y),\% } \\
\hline & $\mathrm{X} !$ & $\mathrm{X} 2$ & $\mathrm{X} 3$ & $\mathrm{X} 4$ & Experimental & Predicted \\
\hline 1 & 350 & 7.5 & 30 & $15: 1$ & $4.38 \pm 0.36$ & 4.35 \\
\hline 2 & 450 & 7.5 & 30 & $15: 1$ & $4.45 \pm 0.23$ & 4.35 \\
\hline 3 & 350 & 8.5 & 30 & $15: 1$ & $5.31 \pm 0.31$ & 5.21 \\
\hline 4 & 450 & 8.5 & 30 & $15: 1$ & $5.26 \pm 0.09$ & 5.32 \\
\hline 5 & 350 & 7.5 & 50 & 15:1 & $4.80 \pm 0.31$ & 4.73 \\
\hline 6 & 450 & 7.5 & 50 & $15: 1$ & $4.81 \pm 0.63$ & 4.78 \\
\hline 7 & 350 & 8.5 & 50 & $15: 1$ & $4.90 \pm 0.24$ & 5.06 \\
\hline 8 & 450 & 8.5 & 50 & $15: 1$ & $5.29 \pm 0.16$ & 5.21 \\
\hline 9 & 350 & 7.5 & 30 & $25: 1$ & $4.42 \pm 0.20$ & 4.40 \\
\hline 10 & 450 & 7.5 & 30 & $25: 1$ & $4.41 \pm 0.20$ & 4.37 \\
\hline 11 & 350 & 8.5 & 30 & $25: 1$ & $5.30 \pm 0.01$ & 5.44 \\
\hline 12 & 450 & 8.5 & 30 & $25: 1$ & $5.53 \pm 0.08$ & 5.51 \\
\hline 13 & 350 & 7.5 & 50 & $25: 1$ & $4.97 \pm 0.40$ & 5.02 \\
\hline 14 & 450 & 7.5 & 50 & $25: 1$ & $5.05 \pm 0.19$ & 5.04 \\
\hline 15 & 350 & 8.5 & 50 & $25: 1$ & $5.53 \pm 0.09$ & 5.53 \\
\hline 16 & 450 & 8.5 & 50 & $25: 1$ & $5.51 \pm 0.04$ & 5.65 \\
\hline 17 & 300 & 8 & 40 & $20: 1$ & $5.32 \pm 0.15$ & 5.26 \\
\hline 18 & 500 & 8 & 40 & $20: 1$ & $5.32 \pm 0.12$ & 5.38 \\
\hline 19 & 400 & 7 & 40 & $20: 1$ & $3.74 \pm 0.18$ & 3.88 \\
\hline 20 & 400 & 9 & 40 & $20: 1$ & $5.49 \pm 0.16$ & 5.35 \\
\hline 21 & 400 & 8 & 20 & $20: 1$ & $5.07 \pm 0.13$ & 5.13 \\
\hline 22 & 400 & 8 & 60 & $20: 1$ & $5.72 \pm 0.13$ & 5.65 \\
\hline 23 & 400 & 8 & 40 & $10: 1$ & $4.33 \pm 0.29$ & 4.43 \\
\hline 24 & 400 & 8 & 40 & $30: 1$ & $5.02 \pm 0.51$ & 4.91 \\
\hline 25 & 400 & 8 & 40 & $20: 1$ & $5.43 \pm 0.21$ & 5.36 \\
\hline 26 & 400 & 8 & 40 & $20: 1$ & $5.37 \pm 0.28$ & 5.36 \\
\hline 27 & 400 & 8 & 40 & $20: 1$ & $5.29 \pm 0.23$ & 5.36 \\
\hline 28 & 400 & 8 & 40 & $20: 1$ & $5.26 \pm 0.19$ & 5.36 \\
\hline 29 & 400 & 8 & 40 & $20: 1$ & $5.40 \pm 0.02$ & 5.36 \\
\hline
\end{tabular}

$\mathrm{X}_{1}:$ ultrasonic power, $\mathrm{X}_{2}: \mathrm{pH}, \mathrm{X}_{3}$ : Extraction time, $\mathrm{X}_{4}$ : solvent/meal ratio.

\section{Results and Discussion}

Proximate analysis of malted sorghum flour: The proximate analysis of malted sorghum flour is presented in Table 3 . The sorghum had a protein content of $11.41 \mathrm{~g} / 100 \mathrm{~g}$ dry solids considered adequate for protein recovery. The majority of sorghum proteins are found within the endosperm of the kernel, distributed within both protein bodies and the endosperm's protein matrix. The major sorghum protein fractions are prolamins and glutelins, with prolamins predominating. The prolamins in sorghum is kafirin-a protein similar to maize zein in molecular weight, structure, solubility, and amino acid composition ( $\mathrm{Da}$ and Taylor, 2005). Kafirin is found to predominate in three forms: $\alpha$-, $\beta$-, and $\gamma$-kafirin, with $\alpha$-kafirin being the major form (Musigakun and Thongngam, 2007). These sorghum prolamins are located within the protein bodies in the starchy endosperm (Taylor et al., 1984). Like many cereals, the limiting amino acid in sorghum is lysine (Waniska and Rooney, 2000).

Table 3. Proximate composition of malted sorghum flour

\begin{tabular}{cc}
\hline Parameters & $\begin{array}{c}\text { Composition, g/100g dry } \\
\text { solids }\end{array}$ \\
\hline Moisture & $9.70 \pm 0.04$ \\
Crude fat & $3.60 \pm 0.11$ \\
Crude protein $(\mathrm{Nx} 6.25)$ & $11.41 \pm 0.08$ \\
Ash & $2.69 \pm 0.06$ \\
Carbohydrate & $59.58 \pm 0.12$ \\
\hline
\end{tabular}

Fitting the models: Malted sorghum flour was extracted for its protein following 29 combinations of four independent variables (ultrasonic power, $\mathrm{pH}$, extraction time, solvent/meal ratio) (Table 1). Results revealed that the experimental protein yield varied from 3.74 to $5.53 \mathrm{~g}$ soluble protein $/ 100 \mathrm{~g}$ malted sorghum flour. Quanhang and Caili (2005) found that the protein yield was $2.77-7.86 \mathrm{~g}$ protein/100 g germinant pumpkin seeds. Liadakis et al., (1995) extracted $43.9-57.3 \%$ of the proteins contained in tomato seed meal.

The application of RSM yields the following regression equation, which is an empirical relationship between protein yield and the test variable in coded units, as given in the following equation.

\section{Final equation in terms of actual factors}

\section{Protein extraction}

$$
\begin{aligned}
\mathrm{Y}= & 5.37+0.030 \mathrm{X}_{1}+0.37 \mathrm{X}_{2}+0.13 \mathrm{X}_{3}+0.12 \mathrm{X}_{4}-0.011 \mathrm{X}_{1}^{2}- \\
& 0.19 \mathrm{X}_{2}^{2}+0.0074 \mathrm{X}_{3}^{2}-0.17 \mathrm{X}_{4}^{2}+0.024 \mathrm{X}_{1} \mathrm{X}_{2}+0.012 \mathrm{X}_{1} \mathrm{X}_{3} \\
& -0.009 \mathrm{X}_{1} \mathrm{X}_{4}-0.13 \mathrm{X}_{2} \mathrm{X}_{3}+0.044 \mathrm{X}_{2} \mathrm{X}_{4}+0.061 \mathrm{X}_{3} \mathrm{X}_{4}
\end{aligned}
$$

The predicted values of protein yields were calculated using the regression model and compared with experimental values in Figure 1. The total determination coefficient $\left(R^{2}\right)$ was $96.7 \%$, indicating a reasonable fit of the model to the experimental data. Earlier studies have reported values for $\mathrm{R}^{2}$ ranging from 58.5 to $99.03 \%$ for watermelon seed (Wani et al., 2006), peanut (Rustom et al., 1991), germinant pumpkin seed (Quanhang and Caili, 2005), amaranth seed (Saloedo et al., 2002), flaxseed (Oomah et al., 1994) and tomato seed (Liadakis et al., 1995).

The significance of each coefficient was determined using the Student t-test and $\mathrm{p}$-value. Solvent/meal ratio, $\mathrm{pH}$ and extraction time were the most significant factors $(p<0.001)$. Especially, $\mathrm{pH}$ and solvent/meal ratio showed highly significant $(p<0.001)$ at linear and quadratic terms. An interaction effect of $\mathrm{pH}$ and solvent/meal ratio was significant $(\mathrm{p}<0.05)$ and ultrasonic power was not significant factor. Liadakis et al., (1995) and Wani et al., (2006) reported a similar effect. 


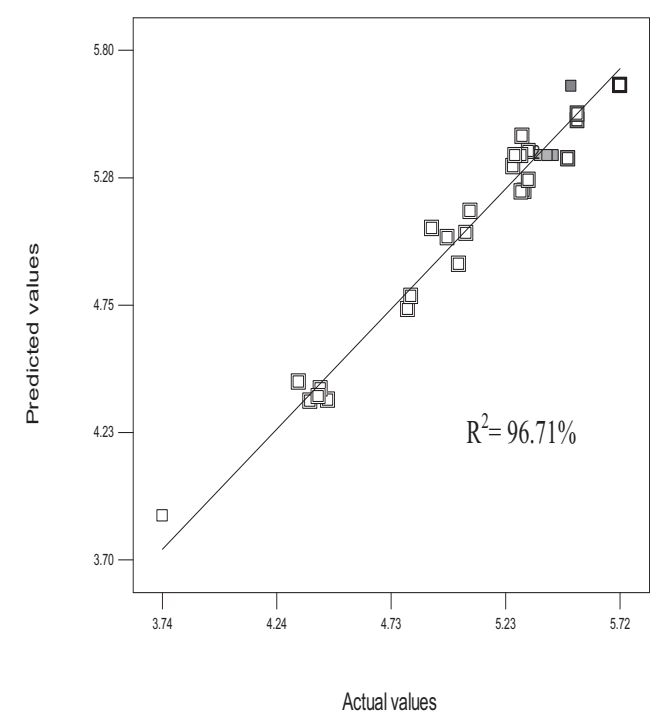

Figure 1. Comparison between predicted and observed protein yield ( $\mathrm{g}$ soluble protein/100 g flour)

Analysis of variance (ANOVA) of independent variables was performed. The statistical analysis data revealed that linear, quadratic and interaction terms were significant $(\mathrm{p}<0.05)$. The lack of fit test measures the failure of the model to represent data in experimental domain at points which are not included in the regression. There was a non-significant lack of fit that further validates the model $(\mathrm{p}>0.05)$ (Table 4$)$. The coefficient of variation (CV) is the ratio of the standard error of estimate to the mean value of observed response expressed as a percentage. It is a measure of reproducibility of the models. The CV of the model was calculated as $2.31 \%$. As a general rule, a model can be considered reasonably reproducible if its $\mathrm{CV}$ is not greater than $10 \%$.

Table 4. Analysis of variance (ANOVA) on the effect of protein extraction condition

\begin{tabular}{|c|c|c|c|c|c|}
\hline Source & $\begin{array}{c}\text { Sum of } \\
\text { Squares }\end{array}$ & df & $\begin{array}{c}\text { Mean } \\
\text { Square }\end{array}$ & F-Value & $\begin{array}{l}\text { p-value } \\
\text { prob }>\text { F }\end{array}$ \\
\hline Model & 6.0719 & 14 & 0.4337 & 31.4458 & $0.0001 *$ \\
\hline A-Temp. & 0.0210 & 1 & 0.0210 & 1.5271 & 0.2355 \\
\hline B-pH & 3.2479 & 1 & 3.2479 & 235.4918 & $0.0001 *$ \\
\hline C-Et(mixing) & 0.4040 & 1 & 0.4040 & 29.2947 & $0.0001 *$ \\
\hline D-RMS & 0.3542 & 1 & 0.3542 & 25.6878 & $0.0001 *$ \\
\hline $\mathrm{AB}$ & 0.0093 & 1 & 0.0093 & 0.6786 & 0.4229 \\
\hline $\mathrm{AC}$ & 0.0024 & 1 & 0.0024 & 0.1776 & 0.6794 \\
\hline $\mathrm{AD}$ & 0.0012 & 1 & 0.0012 & 0.0939 & 0.7634 \\
\hline $\mathrm{BC}$ & 0.2819 & 1 & 0.2819 & 20.4434 & $0.0004 * *$ \\
\hline $\mathrm{BD}$ & 0.0308 & 1 & 0.0308 & 2.2331 & 0.1558 \\
\hline $\mathrm{CD}$ & 0.0601 & 1 & 0.0601 & 4.3609 & 0.0542 \\
\hline $\mathrm{A}^{2}$ & 0.0030 & 1 & 0.0030 & 0.2231 & 0.6434 \\
\hline $\mathrm{B}^{2}$ & 0.9613 & 1 & 0.9613 & 69.7053 & $0.0001 *$ \\
\hline $\mathrm{C}^{2}$ & 0.0015 & 1 & 0.0015 & 0.10908 & 0.7458 \\
\hline $\mathrm{D}^{2}$ & 0.8170 & 1 & 0.8170 & 59.2403 & $0.0001 *$ \\
\hline Residual & 0.2068 & 15 & 0.0137 & & \\
\hline Lack of Fit & 0.1840 & 10 & 0.0184 & 4.0225 & 0.0689 \\
\hline Pure Error & 0.0228 & 5 & 0.0045 & & \\
\hline Cor Total & 6.2788 & 29 & & & \\
\hline
\end{tabular}

Optimization of the process: The 3D surface plots were drawn to illustrate the main and interactive effects of the independent variables on the dependent one. These graphs were obtained by fixing two variables at coded zero level (Table 2) while varying the remaining two variables and predicting the response variable (protein yield).

Figure $2 \mathrm{a}$ shows the effect of ultrasonic power and $\mathrm{pH} ; \mathrm{pH}$ exerted a quadratic effect on protein production, whereas ultrasonic power had a linear effect. Ultrasonic power did not seem to affect protein extraction in the selected range whereas extraction time exerted a linear effect, as shown in Figure $2 b$ Figure 2c shows the effect of the ultrasonic power and of solvent/meal ratio (SMR) on protein production. A quadratic effect of solvent/meal ratio and linear effect of ultrasonic power on the response were observed.

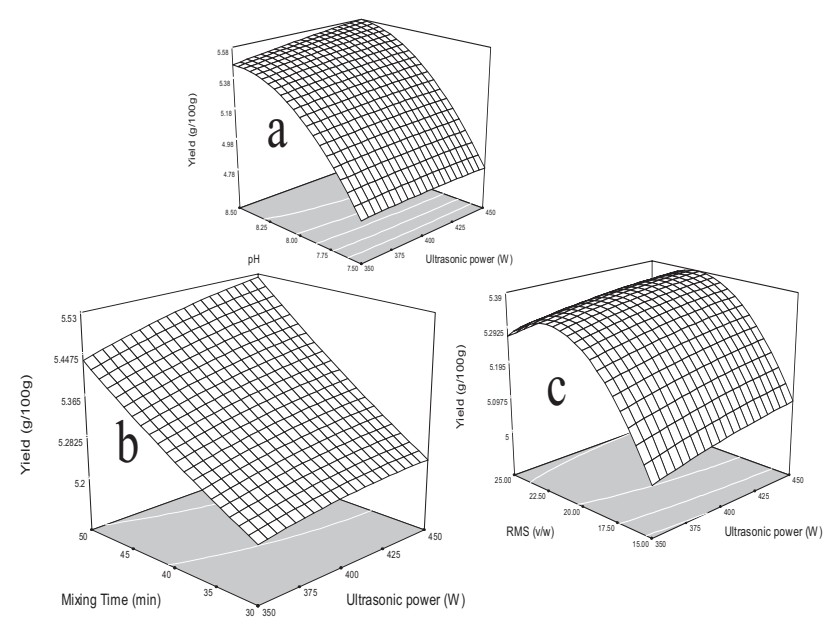

Figure 2. Surface plots for protein yield of malted sorghum flour; (a) Effect of ultrasonic power power and $\mathrm{pH}$ on protein yield with extraction time $\mathbf{4 0} \mathrm{min}$, solvent (water)/meal ratio 20:1 (v/w); (b) Effect of ultrasonic and extraction time on protein yield with $\mathrm{pH} 8.0$, solvent water)/meal ratio $20: 1$ (v/ w); (c) Effect of ultrasonic power and solvent (water)/meal ratio on protein yield with extraction time $40 \mathrm{~min}, \mathrm{pH} \mathbf{8 . 0}$.

The graph shown in Figure $3 \mathrm{a}$ indicates that both $\mathrm{pH}$ and extraction time had a quadratic effect on protein extraction. Figure $3 \mathrm{~b}$ depicts the influence of $\mathrm{pH}$ and solvent/meal ratio; it can be seen as a quadratic effect for both $\mathrm{pH}$ and solvent/ meal ratio. The results indicated that the increase in $\mathrm{pH}$ and solvent/meal ratio extracted higher amount of protein from malted sorghum flour. Effect of extraction time and solvent/ meal ratio on protein yield is presented in Figure $3 \mathrm{c}$.

The results revealed that extraction time did not have any significant effect on the protein extraction while an increase in solvent/meal ratio showed an increasing trend for protein extraction. Considering all the response, it is evident that solvent/meal ratio, extraction time and $\mathrm{pH}$ had a significant effect on protein yield while the effect of ultrasonic power was more limited. 


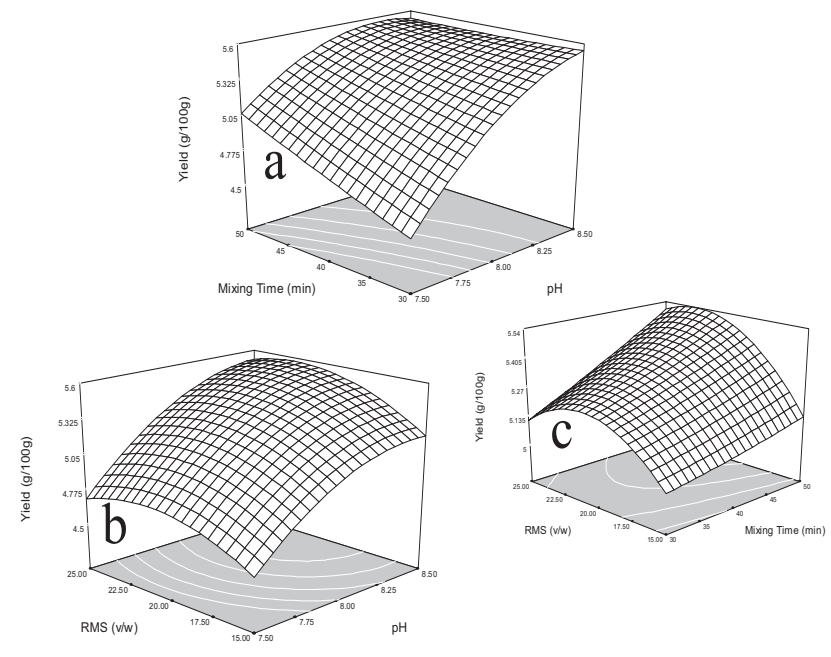

Figure 3. Surface plots for protein yield of malted sorghum flour; (a) Effect of $\mathrm{pH}$ and extraction time on protein yield with ultrasonic power $400 \mathrm{~W}$, solvent (water)/meal ratio 20:1 (v/w); (b) Effect of $\mathrm{pH}$ and solvent (water)/meal ratio on protein yield with ultrasonic power $400 \mathrm{~W}$, extraction time $40 \mathrm{~min}$; (c) Effect of extraction time and solvent/ meal ratio on protein yield with ultrasonic power $400 \mathrm{~W}$, pH 8.0.

Optimum extraction conditions were estimated by the desirability method using a Design-Expert 7.1 Software. A solvent/meal ratio of $20: 1(\mathrm{v} / \mathrm{w})$, extraction time of $40 \mathrm{~min}, \mathrm{pH}$ of 8 and ultrasonic of $400 \mathrm{~W}$ were found to be optimal in range for protein extraction from malted sorghum flour. Ghavidel and Prakash (2006) reported that flours obtained from ungerminated green gram, cowpea and Bengal gram had a broad apparent isoelectric $\mathrm{pH}$ range 3-5 and the highest solubility of the protein for germinated samples occurred at pH 6. Normally the protein solubility characteristics are influenced by factors such as origin, processing conditions, $\mathrm{pH}$, ionic strength and the presence of other ingredients (Kinsella, 1976). The proteins of the germinated samples are more soluble and this might be due to the high proteolysis activity during germination which leads to an increase in the protein solubility resulting from hydrolysis of the storage proteins.

Studies of the extraction of malted sorghum flour protein could not be traced; however, similar studies using other plant material have been reported. Quanhang and Caili (2005) worked on protein extraction from germinated pumpkin seed and found significant effects of solvent/meal ratio and concluded that optimum conditions were: solvent/meal ratio of 30.2:1 (v/w), $\mathrm{NaCl}$ concentration of $4.26 \%$ and a reaction time of $18.1 \mathrm{~min}$. Wani et al., (2006) studied the extraction of watermelon seed protein and concluded that maximum protein yield was obtained by extracting seed meal with a $\mathrm{NaOH}$ concentration of $1.2 \%$, solvent $/ \mathrm{meal}$ ratio of $70: 1$, extraction time of $15 \mathrm{~min}$ and ultrasonic of 400W. Liadakis et al., (1995) worked on protein extraction from tomato seed and found that optimum extraction could be achieved by extracting one part of tomato seed meal with 30 parts of water (w/v) at $\mathrm{pH} 11.5$ at $50^{\circ} \mathrm{C}$ for 20 min. Rustom et al., (1991) reported that significant effects of time, temperature, $\mathrm{pH}$ and solvent/meal ratio were found and concluded that optimum extraction were: $\mathrm{pH}$ of 8.0, time of 30 min; temperature of $50^{\circ} \mathrm{C}$ and solvent/meal ratio of 8.1 . Mizubuti et al., (2000) state that optimum conditions for protein extraction from pigeon pea were no $\mathrm{NaCl}, \mathrm{pH} 8.5$ and solvent/meal ratio 5.1. Oomah et al., (1994) determined that solvent to meal ratio of $10: 1 \mathrm{per} \mathrm{kg}, 0.8 \mathrm{~mol} / \mathrm{L} \mathrm{NaCl}$ and $\mathrm{pH} 8.0$ were optimum conditions for extracting protein from flaxseed meal.

Confirmative tests: The suitability of the model equation for predicting the optimum response value was tested using the recommended optimum conditions. When optimum values of independent variables (ultrasonic power $400 \mathrm{~W}$, solvent/meal ratio $20: 1 \mathrm{v} / \mathrm{w}$, extraction time $40 \mathrm{~min}, \mathrm{pH} 8.0$ ) were incorporated into the regression equation, $5.36 \mathrm{~g} / 100 \mathrm{~g}$ protein yield was obtained whereas experiments at optimum conditions gave a protein yield of $5.43 \mathrm{~g} / 100 \mathrm{~g}$. Thus, predicted values from fitted equations and observed values were in very good agreement.

\section{Conclusion}

Protein was extracted from malted sorghum flour using response surface methodology with 29 selected combinations of ultrasonic power, $\mathrm{pH}$, solvent/meal ratio and extraction time. The experimental value of protein yield varied from 3.74 to $5.53 \mathrm{~g}$ soluble protein $/ 100 \mathrm{~g}$ malted sorghum flour. The second order polynomial model developed for protein yield exhibited a non-significant value for lack of fit and high value for the coefficient of determination. The variables which showed greatest effect on the extraction yield of protein were the $\mathrm{pH}$ and solvent/meal ratio. Optimum extraction of malted sorghum protein with water could be achieved by extracting one part of malted sorghum meal with 20 parts of water (w/v ratio) at $\mathrm{pH} 8$ at $400 \mathrm{~W}$ for $40 \mathrm{~min}$. These conditions resulted in protein yield of $5.43 \mathrm{~g}$ of soluble protein from extract/100 $\mathrm{g}$ malted sorghum flour. The response surface methodology technique proved to be a useful tool in establishing optimum conditions for extracting of protein from malted sorghum flour.

\section{References}

Abdul K., Zahid A. C., Muhamad A. M. and Shahzad M. A. B. (1999). Evaluation of Sorghum (Sorghum bicolor) Water Extract for Weed Control in Soybean. Int. J. Agri. Biol., 1: 23-26.

Aluko R. E. and McIntosh T. (2001). Polypeptide profile and functional properties of defatted meals and protein isolates of canola seeds. J. of the Sci. of Food and Agric., 81:391-396.

Aluko R. E., McIntosh T., and Katepa-Mupondwa, F. (2005). Comparative study of the polypeptide profiles and functional properties of Sinapis alba and Brassicajuncea seed meals and protein concentrates. J. of the Sci. of Food and Agric., 85: 1931-1937. 
Anglani C., 1998. Sorghum for human food: a review. Plant Foods Hum. Nutr., 52: 85-89.

AOAC (1997). Official methods of analysis of the association of official analytical chemists. Virginia, USA: AOAC Inc.

Bilgi B. and Celik S. (2004). Solubility and emulsifying properties of barley protein concentrate. Eur. Food Res. Technol., 218: 437-441.

Chavan U. D., McKenzie D. B. and Shadidi, F. (2001). Functional properties of protein isolates from beach pea (Lathyrus maritimus L.). Food Chem., 74: 177-187.

Chove B. E., Grandison A. S. and Lewis M. J. (2001). Emulsifying properties of soy protein isolate fractions obtained by isoelectric precipitation. J. of the Sci. of Food and Agric., 81: 759-763.

Da Silva L.S. and Taylor J.R.N. (2005). Physical, mechanical, and barrier properties of kafirin films from red and white sorghum milling fractions. Cereal Chem., 82:9-14.

Elkhalifa A. O., Schiffler B. and Bernhardt R. (2005). Effect of fermentation on the functional properties of sorghum flour. Food Chemistry, 92: 1-5.

Food and Agricultural Organization (FAO), 1995. Sor-ghum and millet in human nutrition. FAO Food and Nutrition Series No. 27. ISBN 92-5-103381-1.

Food and Agricultural Organization (FAO), 2002. United Nations Food and Agriculture Organization. Protein Sources for the animal feed industry. Animal Production and Health paper No1. Retrieved from:|http:// www.fao.org/docrep/007/ y5019e/y5019e00.HTM, (Retrieved from: May 03, 2002).

Ghavidel R. A. and Prakash J. (2006). Effect of germination and dehulling on functional properties of legume flours. $J$. of the Sci. of Food and Agric., 86: 1189-1195.

Hoseney R. C., 1994. Principles of Cereal Science and Technology. $2^{\text {nd }}$ Edn, St Paul, MN, USA: American Association of Cereal Chemists, Inc.

Kinsella J. E. (1976). Functional properties of protein in foods, a survey. CRC Critical Review Food Science and Nutrition, 7: 219-280.

Liadakis G. N., Tzia C., Oreopoulou V. and Thomopoulos C. D. (1995). Protein isolation from tomato seed meal extraction optimization. J. of Food Sci., 60: 477-482.

Liadakis G. N., Tzia C., Oreopoulou V. and Thomopoulos C. D. (1998). Isolation of tomato seed meal proteins with salt solutions. J. of Food Sci., 63:450-453.

Lowry O. H., Rosebrough N. J., Farr A. L. and Randal R. J. (1951). Protein analysis with Folin-phenol reagent. J. of Biol. Chem., 193:265-275.

Lqari H., Pedroche V. J. and Millan F. (2002). Lupinus angustifolius protein isolates: chemical composition, functional properties and protein characterization. Food Chem., 76:349-356.

Mizubuti I. Y., Junior O. B., Souza L. W. O., Silva R. S. S. F. and Ida E. I. (2000). Response surface methodology for extraction optimization of pigeon pea protein. Food Chem., 70: 259-265.

Moure A., Rua M., Sinerio J. and Dominguez H. (2002). Aqueous extraction and membrane isolation of protein from defatted Guevina avellana. J. of Food Sci., 67: 688696.

Muhammad J., Zahid A. and Abdul K. (2005). Increasing the Efficiency of Sorghum Water Extract (Sorgaab) by Mixing with Lower Doses of Isoproturon to Control Weeds in Wheat. Int. J. Agri. Biol., 7:712-718.

Musigakun P. and Thongngam M. (2007). Characteristics and functional properties of sorghum protein (kafirin). Kasetsart J. Nat. Sci. 41:313-318.

Mwasaru M. A., Muhammed K., Bakar J. and Man Y. B. C. (2000). Influence of altered solvent environment on the functionality of pigeonpea (Cajanus cajan) and cowpea (Vigna unguiculata) protein isolates. Food Chem., 71:157-165.

Nakai S., Li-Chen E. C. Y. and Dou J. (2006). Experimental design and response surface methodology. In: S. Sablani, A. Datta, M. S. Rahman and A. Mujumdar (Eds.), Handbook of food and bioprocess modeling techniques, Vol. 1 (pp. 293-323). Boca Raton: CRC Press.

Oomah B. D., Mazza G. and Cui W. (1994). Optimization of protein extraction from flaxseed meal. Food Res. Int., 27: 355-361.

Qiao D. L., Kea C. L., Hua B., Luo J.G., Ye H. and Sun Y. (2009). Antioxidant activities of polysaccharides from Hyriopsis cumingii. Carbohyd. Polym., 78: 199-204.

Quanhang L. and Caili F. (2005). Application of response surface methodology for extraction of germinant pumpkin seeds protein. Food Chem., 92:701-706.

Randhawa M.A., Cheema Z.A. and Muhammad A. (2002). Allelopathic effect of sorghum water extract on the germination and seedling growth of Trianthema portulacastrum, Int. J. Agri. Biol., 4: 383-384.

Rustom I. Y. S., Lopez-Leiva M. H. and Nair B. M. (1991). Optimization of extraction of peanut proteins with water by response surface methodology. J. of Food Sci., 56:1660-1663.

Saloedo-Chavez B., Osuna-Castro J.A., Guevara-Lara F., Dominguez-Dominguez J. and Paredes-Lopez O. (2002). Optimization of the isoelectric precipitation method to obtain protein isolates from amaranth (Amaranthus cruentus) seeds J. of Agric. and Food Chem., 50: 65156520.

Taylor J. R. N., Novellie L. and Liebenberg N. V. W. (1984). Sorghum protein body composition and ultrastructure. Cereal Chem., 61:69-73.

Wani A. A., Sogi D. S. Grover L. and Saxena D. C. (2006). Effect of temperature, alkali concentration, extraction time and meal/solvent ratio on the extraction of watermelon seed proteins-a response surface approach. Biosystems Engineering, 94: 67-73.

Waniska R. D. and Rooney L. W. (2000). Sorghum food and industrial utilization. In: Smith, C.W. and Frederiksen R.A. editors. Sorghum: Origin, history, technology, and production. Canada: John Wiley and Sons, Inc. p 689729.

Wang Y. D. and Fields M. L. (1978). Germination of corn and sorghum in the home to improve nutritive value. $J$. of Food Sci., 43:1113-1115. 